\title{
Demography gone wild in native species: four reasons to avoid the term "native invaders"
}

\author{
M. Méndez, A. Escudero, J. M. Iriondo, and R. M. Viejo \\ Área de Biodiversidad y Conservación, Universidad Rey Juan Carlos, c/ Tulipán s/n., 28933 Móstoles, \\ Madrid, Spain \\ Correspondence to: M. Méndez (marcos.mendez@urjc.es)
}

Received: 14 October 2014 - Revised: 3 December 2014 - Accepted: 4 December 2014 - Published: 14 January 2015

The definition and application of the concepts "invasive" and "invader" have been a subject of discussion among ecologists for over a decade and, as a consequence, different authors have suggested a panoply of terms to cover all the situations (Davis and Thompson, 2000; Richardson et al., 2000; Colautti and MacIsaac, 2004; Blackburn et al., 2011; Kowarik and Pyšek, 2012). Typically, further dispersal and increase in numbers after arrival in a new territory have been considered fundamental in this terminology (Richardson et al., 2000; Colautti and MacIsaac, 2004; Wilson et al., 2009; Richardson and Ricciardi, 2013). In our view, the use of the term "native invaders" adds a discomforting twist to this apparently settled controversy.

"Native invaders" is a label recently introduced (Valéry et al., 2008; Simberloff, 2011) to designate "species that have become "invasive" in their own native range" (Carey et al., 2012). Native invaders have, according to this definition, increased in numbers so as to become a nuisance. We will refer to this situation as demographic disregulation. This is what Valéry et al. (2008) consider the core aspect of invasiveness, while they dismiss human transport to a new territory as irrelevant. Although this situation clearly presents management challenges, recently reviewed by Carey et al. (2012), we question the need and convenience of the term "native invader". From a purely semantic view, the available terminology can account for all cases of demographic disregulation of natural populations, both within and beyond their historical range. For example, in the botanical literature, "apophyte" - a term that can be traced back at least to the late 1960s (Holub and Jirásek, 1967), although not widely utilized refers to species which increase their numbers or modify their demographic cycles within their ranges due to anthropogenic causes. Thus, the framework proposed by Richardson et al. (2000) and Didham et al. (2005) covers what most researchers consider non-indigenous naturalized and invasive species. Terms for the diffusion-like expansion of populations beyond their historical range have also been considered by Davis and Thompson (2000).

Some researchers consider terminological controversies to be purely semantic and trivial. By contrast, we contend that labelling some native species as invaders has deep management implications, because they directly affect how invasiveness is conceived. We believe that emphasizing demographic increase, while dismissing previous anthropogenic dispersal (Valéry et al., 2008), does not convey an appropriate conceptualization of invasion biology on four grounds: (1) it adds nothing to an already well-known management problem, (2) it can bias the perception of management options of some stakeholders and create more damage than benefit, (3) it neglects the fact that different causes underlie the disregulation of native and non-indigenous species, and (4) it deliberately excludes some species that can also become disregulated for anthropogenic reasons, thus adding to the confusion. We elaborate on these four criticisms below.

Deterioration of ecosystem services and other economic drawbacks caused by anthropogenically disregulated native populations is already well known among scientists and managers. A few examples from the Iberian Peninsula where we work are the management of wildboar Sus scrofa populations lacking predators (Sáez-Royuela and Tellería, 1986), of seagulls Larus cachinnans getting extra food supplies from human waste (Vidal et al., 1998), of magpies Pica pica dominating bocage landscapes (Díaz-Ruiz et al., 2010) or amphibian extinction by brown trout Salmo trutta stocked in fishless ponds (Orizaola and Braña, 2006). A new, catchy name for an old problem contributes little or nothing to solving it. On the contrary, this term can easily be pushed to absurd extremes. For example, pine species which have been delib- 
erately stocked in their native area beyond historical numbers and which strongly influence the natural fire regime in Mediterranean areas (Barbero et al., 1990) could be considered native invaders.

Furthermore, using the value-laden "invader" in these cases can tip the balance against some species perceived as a nuisance by some influential stakeholders. Are the shags Phalacrocorax carbo really so damaging for the already overexploited salmon fisheries in the northern Iberian Peninsula (Álvarez, 2009)? Should the wolf, Canis lupus, which is regaining its historically lost quarters in the central and eastern Iberian peninsula (Alonso et al., 2012), be considered a native invader? Once the label "invader" is attached to a species, perception can be dangerously biased. This can be particularly misleading in regions such as the Mediterranean Basin, where man-induced changes go back for more than 8000 years. What is the reference ecosystem to use in order to decide if a particular species is rapidly spreading in a disregulated way or simply recovering a past equilibrium (Balaguer et al., 2014)?

What can be learnt from pooling native and nonindigenous demographically successful species under a common label? We believe that the underlying ecological processes and the consequences derived from the demographic expansion within or beyond a species' historical range are so different that pooling them under the same term is misleading (see Richardson and Ricciardi, 2013, for a similar reasoning). For example, the important distinction between drivers and passengers (Didham et al., 2005) developed for non-indigenous invaders is of little use for native invaders; all native invaders are passengers, or collateral damages of human alterations of the environment. By definition, there is no such thing as a driver native invader, because a historically abundant species is not perceived as an invader, but as an abundant species. Furthermore, the possibilities of controlling the disregulated demography of a species differ greatly among native and non-indigenous invaders. Historical adjustment to abiotic factors and natural enemies is radically different among native and non-indigenous invaders (Wilson et al., 2009), and leads to important evolutionary differences (Colautti and MacIsaac, 2004). Non-indigenous invaders lack a coevolutionary history that is present in native invaders, although non-indigenous species are liable to evolve rapidly in the invaded territory (Cox, 2004).

Finally, the term "native invader" deliberately excludes those populations showing recurrent increases in numbers (Simberloff, 2011). However, those species could modify their peak numbers or the frequency of demographic increases as a consequence of anthropogenic modifications of the environment. They are as liable to become nuisance species as any other native, anthropogenically disregulated species.

Native disregulated populations pose a management challenge that will potentially increase in the current scenario of global change (Battisti et al., 2005). However, we discourage the use of "native invader", as it does not suggest any fruitful management guideline, may lead to wrong management decisions, and potentially hinder the advancement of invasion biology research.

Acknowledgements. We thank Lori J. De Hond for her linguistic assistance. This work was partially financed by Project MOUNTAINS (CGL2013-38427) financed by the Spanish Government.

Edited by: D. Montesinos

\section{References}

Alonso, O., Laso, R., and Martín, D.: El lobo cría en la Comunidad de Madrid, Quercus, 321, 16-25, 2012.

Álvarez, D.: Descastes de cormorán grande: historia de un despropósito, Quercus, 282, 80-81, 2009.

Balaguer, L., Escudero, A., Martín-Duque, J. F., Mola, I., and Aronson, J.: The historical reference in restoration ecology:redefining a cornerstone concept, Biol. Conserv., 176, 12-20, 2014.

Barbero, M., Bonin, G., Loisel, R., and Quézel, P.: Changes and disturbances of forest ecosystems caused by human activities in the western part of the mediterranean basin, Vegetatio, 87, 151173, 1990.

Battisti, A., Stastny, M., Netherer, S., Robinet, C., Schopf, A., Roques, A., and Larsson, S.: Expansion of geographic range in the pine processionary moth caused by increased winter temperatures, Ecol. Appl., 15, 2084-2096, 2005.

Blackburn, T. M., Pyšek, P., Bacher, S., Carlton, J. T., Duncan, R. P., Jarosik, V., Wilson, J. R. U., and Richardson, D. M.: A proposed unified framework for biological invasions, Trends Ecol. Evol., 26, 333-339, 2011.

Carey, M. P., Sanderson, B. L., Barnas, K. A., and Olden, J. D.: Native invaders - challenges for science, management, policy, and society, Front. Ecol. Environ., 10, 373-381, 2012.

Colautti, R. I. and MacIsaac, H. J.: A neutral terminology to define 'invasive' species, Divers. Distrib., 10, 135-141. 2004.

Cox, G. W.: Alien species and evolution: the evolutionary ecology of exotic plants, animals, microbes, and interacting native species, Island Press, Washington DC, 377 pp., 2004.

Davis, M. A. and Thompson, K.: Eight ways to be colonizer; two ways to be an invader: a proposed nomenclature scheme for Invasion Ecology, Bull. Ecol. Soc. Am., 81, 226-230, 2000.

Díaz-Ruiz, F., García, J. T., Pérez-Rodríguez, L., and Ferreras, P.: Experimental evaluation of live cage-traps for black-billed magpies Pica pica management in Spain, Eur. J. Wildl. Res., 56, 239248, 2010.

Didham, R. K., Tylianakis, J. M., Hutchinson, M. A., Ewers, R. M., and Gemmell, N. J.: Are invasive species the drivers of ecological change?, Trends Ecol. Evol., 20, 470-474, 2005.

Holub, J. and Jirásek, V.: Zur Vereinheitlichung der Terminologie in der Phytogeographie, Folia Geobot. Phytotax., 2, 69-113, 1967.

Kowarik, I. and Pyšek, P.: The first steps towards unifying concepts in invasion ecology were made one hundred years ago: revisiting the work of the Swiss botanist Albert Thellung, Divers. Distrib., 18, 1243-1252, 2012.

Orizaola, G. and Braña, F.: Effect of salmonid introduction and other environmental characteristics on amphibian distribution 
and abundance in mountain lakes of northern Spain, Anim. Conserv., 9, 171-178, 2006.

Richardson, D. M., Pyšek, P., Rejmánek, M., Barbour, M. G., Panetta, F. D. and West, C. J.: Naturalization and invasion of alien plants: concepts and definitions, Divers. Distrib., 6, 93-107, 2000.

Richardson, D. M. and Ricciardi, A.: Misleading criticisms of invasion science: a field guide, Divers. Distrib., 19, 1461-1467, 2013.

Sáez-Rouela, C. and Tellería, J. C.: The increased population of the wild boar (Sus scrofa L.) in Europe, Mammal Rev., 16, 97-101, 1986.

Simberloff, D.: Native invaders, in: Encyclopedia of biological invasions, edited by: Simberloff, D. and Rejmánek, M., University of California Press, Berkeley and Los Angeles, CA, 472-475, 2011.
Valéry, L., Fritz, H., Lefeuvre, J.-C., and Simberloff, D.: In search of a real definition of the biological invasion phenomenon itself, Biol. Inv., 10, 1345-1351, 2008.

Vidal, E., Medail, F., and Tatoni, T.: Is the yellow-legged gull a superabundant bird species in the Mediterranean? Impact on fauna and flora, conservation measures and research priorities, Biodivers. Conserv., 7, 1013-1026, 1998.

Wilson, J. R. U., Dormontt, E. E., Prentis, P. J., Lowe, A. J., and Richardson, D. M.: Biogeographic concepts define invasion biology. Trends Ecol. Evol., 24, p. 586, 2009. 